九州大学学術情報リポジトリ

Kyushu University Institutional Repository

\title{
活性化膵星細胞を標的とした膵癌治療および新規薬 剂スクリーニング法の開発
}

相良，悪希子

http://hdl. hand le. net/2324/4495968

出版情報: Kyushu University，2021，博士（医学），課程博士 バージョン：

権利関係: Public access to the fulltext file is restricted for unavoidable reason (3) 
論 文 名 : New high-throughput screening detects compounds that suppress pancreatic stellate cell activation and attenuate pancreatic cancer growth

(活性化膵星細胞を標的とした膵癌治療および新規薬剤スクリーニング法 の開発）

区 分：甲

\section{論 文内容 の 要旨}

膵星細胞（Pancreatic stellate cell; PSCs）は、膵癌の豊富な間質（desmoplasia）中で静止 状態から活性状態に移行し、膵癌細胞の悪性度や化学療法抵抗性を六進させている。よ って、PSCの活性化を抑制し、癌間質相互作用を抑制することは、治療戦略として有望 と考えられる。本研究の目的は、PSCの活性化を抑制し、膵癌の増殖を阻害する化合物 を同定することである。静止状態のPSC は、細胞質内に多数の脂肪滴を蓄積することに 着目し、これを定量化して活性状態を評価する新しいスクリーニングシステムを開発し た。米国食品医薬品局が承認した 3398 種類の医薬品のライブラリのスクリーニングを 行い、候補化合物がPSC の活性化を抑制し、マウス膵腫瘍の増殖を抑制するかを検討し た。スクリーニングの結果から、32 種類の化合物を候補化合物として選択した。これら の化合物は、PSCの はSMA（ $\alpha$-smooth muscle actin; $\alpha$ SMA）を減少させ、PSCのオートフ アジーを阻害した。候補化合物の中から選択された 3 種類の薬物は、PSCの増殖と遊走 を抑制し、また癌間質相互作用の抑制を介して膵癌細胞の浸潤を抑制した。マウス同所 移植モデルを用いた実験では、ドパミン拮抗薬ズクロペンチキソールが腫瘍増殖を抑制 し、この抑制効果は既存の抗癌剤ゲムシタビンとの併用療法で顕著に増加した。PSCの 形態学的特徵に着目した新しいスクリーニングシステムは、PSCの活性化を抑制し、膵 癌の増殖を抑制する新たな化合物の発見に寄与すると考えられる。 